\title{
Persistence in STEM Majors: Investigating Whether and When High- Performing Students Leave STEM during Undergraduate Studies
}

\author{
Christopher W. Kohler \\ ${ }^{a}$ University of Buffalo, USA
}

\begin{abstract}
The focus of this study was to investigate the effects of both pre-and post-matriculation academic achievement on the likelihood and timing of high-achieving student departures from STEM majors at elite universities. While there has been robust research on persistence in STEM as a whole, survival analysis to investigate the timing of events is still a novel tool to investigate departure from STEM majors. Using longitudinal data collected at Harvard, secondary analysis was conducted to examine the research questions using discrete-time survival analysis. The researcher found that demographic characteristics of the students in the sample were not significant in predicting time-to STEM major attrition. However, verbal achievement was found to be the most significant predictor of STEM major attrition, with higher levels of verbal achievement leading to higher levels of attrition from STEM majors to non-STEM majors.
\end{abstract}

Keywords: STEM major, STEM attrition, survival analysis, high-achieving students, elite universities

\section{Introduction}

One of the unique aspects of higher education in the United States is the ability to switch academic major once admitted and enrolled at a university. Many students enter university with an intended major, only to change pathways at some point during their undergraduate career. For students entering university with intended majors in Science, Technology, Engineering and Mathematics (STEM), this is even more prevalent (Rask, 2010; Griffith, 2010). The United States has seen a steep decline in the number of STEM degrees conferred as a whole. For example, the number of undergraduate students earning a degree in engineering has decreased by 16 percent from 1985 to 2006 (Kokkelenberg \& Sinha, 2010). Students intending to major in a STEM field at entry to postsecondary education have a lower probability of receiving a degree in their initial major than students beginning their undergraduate studies in other fields, and the least likely students to persist toward a degree in STEM fields are women and historically disadvantaged minority groups (Price, 2010; Kokkelenberg \& Sinha, 2010). In fact, while the population of underrepresented minority groups (African American, Hispanic or Latino/a, and Native American) in the United States in 2010 accounted for 29.3 percent of the total population, only 14.7 percent of the STEM bachelor's degrees awarded in 2010 were attained by members of these groups (Estrada et al., 2016).

As the production of a sufficient number of STEM graduates who are prepared for the workforce in these fields has become a national policy imperative in the United States, the retention of STEM students through graduation is targeted as a means to accomplish this goal (Chen \& Soldner, 2013). The research on factors influencing the retention of students, both in general and in STEM majors, is quite robust; however,

\footnotetext{
${ }^{1}$ Corresponding Author. E-mail: wkohler@buffalo.edu
} 
it is mostly descriptive. Additionally, there is a lack of specific inquiry into the persistence of high-achieving students in STEM majors. Chen \& Soldner (2013) found that the probability of leaving STEM majors for other non-STEM majors was higher in the cohort of high-achieving students than the cohort of low-achieving students. More research is necessary to understand the underlying push and pull of departing STEM majors, particularly among high-achieving students.

\section{Factors Relating to STEM Persistence and Attrition}

When examining STEM persistence, it is important to distinguish the differences between persistence in STEM majors and persistence in higher education as a whole. The current study focuses on the persistence in specific majors, namely STEM majors. Research on student persistence has tended to focus mainly on student dropout instead of investigating students choosing to switch majors without leaving a particular institution (Simon et al., 2015). While the literature on both retention in general and STEM specifically is robust, there is a paucity of studies focusing on students who switch from STEM majors to other majors. A review of the literature focusing on STEM persistence follows.

Vincent Tinto (1993), in his canonical work on student retention, suggests that individual characteristics of students regarding their enrollment in higher education and attendance at a specific institution are important predictors of persistence in a certain field of study, and ultimately towards graduation. Persistence, therefore, is the juxtaposition between both individual factors and institutional factors that are influencing students in their studies. This understanding of persistence was a major shift from previous retention studies focused solely on individual factors, such as student motivation and effort.

The literature related to persistence in STEM majors focuses mainly on three factors: gender, race, and achievement level. The literature on gender differences in postsecondary STEM persistence provides conflicting evidence. While some studies have demonstrated a significant difference in STEM persistence between men and women (Rask, 2010), others have determined that gender differences in persistence are not significant (King, 2016). Still, others have demonstrated both significant and non-significant results based on the type of analysis used (Chen \& Soldner, 2013). These disparate findings muddy the waters when trying to understand gender-related issues in STEM persistence.

King (2016) finds that women are as likely as men to persist in university STEM majors, both in STEM majors with a significant minority of females (computer science, engineering, mathematics, and physical science) as well as the life sciences where women are more equally represented. This finding contrasts with Min, Zhang, Long, Anderson \& Ohland's (2011) study of the loss rate of undergraduate engineering students, particularly that female students leave engineering earlier and at higher rates than do male students.

The negative environment women may experience while pursuing a STEM major may also have a deleterious effect on progression toward degree completion. Women in STEM and setbacks in their progression towards a STEM degree have been shown to be biased by gender-STEM stereotypes (LaCosse, Sekaquaptewa $\&$ Bennett, 2016). When cues in the setting promote this gender stereotype, such as witnessing the negative treatment of other women in a STEM setting, this ultimately lowers women's intentions to remain in STEM fields or pursue STEM careers. Nonverbal stereotype behaviors have shown to be even more detrimental to women's persistence in STEM majors and careers (LaCosse, Sekaquaptewa \& Bennett, 2016).

The "weed-out" system can also be a factor that leads to negative experiences during STEM study, as the predominantly male environment. The fact that STEM fields have been predominantly male makes the social system new and uncomfortable for female students when dealing with their male peers (Seymore \& Hewitt, 1997). This socialization factor of STEM persistence may be a factor in not only the risk of attrition for women in STEM majors but also the timeframe of attrition. As Min, Zhang, Long, Anderson, and Ohland (2011) found, the semester that women are most at risk of departure in engineering majors was during the second year of study. 
The "leaky pipeline" of women in STEM fields continues after graduation, potentially influencing the decision-making of current women pursuing STEM majors. Glass, Sassler, Levitte, and Michelmore (2013) studied female STEM graduates in a nationally representative sample to compare the trajectories of women in STEM versus women in non-STEM professional fields. The results demonstrate that women in STEM fields are dramatically less likely to persist in STEM careers, but not because women are leaving the workforce in general. Women are moving from careers in STEM fields to careers in non-STEM fields at very high rates, and are unlikely to return to the STEM field after attrition. Additionally, the moves tend to take place early on in careers, often within the first five years. This trend is troubling and could be a signal to women in STEM majors to seek out other majors due to the risk of leaving the STEM field even after completing a STEM degree.

Race has been another oft-focused area of study regarding retention, both in general and in STEM fields. Griffith (2010) finds some notable differences in original major and persistence based on race. Of students declaring a STEM major at the point of application, only $47 \%$ of minority students remain in a STEM major by sophomore spring, as compared to $58 \%$ of non-minority students (Griffith, 2010). By senior year, the differential is greater: only $36 \%$ of minority students entering as STEM majors remain by senior year, while $46 \%$ of non-minority students persist to senior year in a STEM major.

Role modeling has been shown to be beneficial to student persistence in STEM, particularly regarding race. Studies have shown that when exposed to faculty of their own gender or race in STEM courses they are more likely to persist. Price (2010) finds a relationship between instructor race and gender and student persistence: students taught by an instructor of the same race are more likely to persist in a STEM major, while female students taking courses with female instructors are less likely to persist in STEM majors. Carrel, Page \& West (2009) found that, while the gender of STEM instructors had little impact on academic performance of male students, it had a great impact on female students' grades in mathematics and science classes, as well as the likelihood of persistence and STEM degree completion. Additionally, the impact was strongest among students with high ability in mathematics as demonstrated on standardized tests. High achieving students in math and science are, in principle, the students whom should be persisting to STEM degrees and entering the STEM field. Studies, such as Price's (2010) indicate that the mechanism driving the result of this role modeling phenomenon is not identified. Influences during their education should be examined to diminish the likelihood of attrition, including facilitating mentor/mentee relationships at certain high-risk times for attrition from STEM majors.

This study aims to explore the factors that lead to whether and, if so, when high-achieving students entering postsecondary study as intended STEM majors decide to change to majors other than STEM. Survival analysis is particularly well suited to investigate this question.

\section{Method}

\section{Sample}

For this study's focus on high-achieving students and STEM major persistence, the researcher was particularly interested in examining the highest-achieving students, particularly ones at the most prestigious universities in the United States. Permission was obtained to use a restricted-use data set from a longitudinal study of concentration choice of students at Harvard University. The data set, Factors Influencing Concentration Choice Among Undergraduates, 1979-1983, was a four-year longitudinal study undertaken to explore the reasons why students entering college with intentions to major in science end up abandoning their plans before they declare a major in their second year of study. These data were collected by Susan Bailey, Barbara Burrell, and Norma Ware and are available through the Henry A. Murray Research Archive of the Institute for Quantitative Social Science at Harvard University, Cambridge, Massachusetts [Producer and Distributor]. The researchers were particularly focused on gender and science majors, examining the factors that seem to facilitate a choice of science majors for women. 
In the summer before their first year at Harvard, 300 students from the classes of 1982 and 1983 were selected to participate in the study. Questionnaires were sent out and collected in August before they entered undergraduate. The questionnaire included information on their background, previous academic achievement, and major choice. In November of their first year, a second questionnaire was sent to the students, expanding on the first questionnaire by including information on experiences at Harvard, particularly in major departments and general college experiences. Subsequently, questionnaires were sent out in the fall of the participants' sophomore, junior and senior year. These questionnaires included information on majors but also expanded on the previous data by asking questions on immediate and long-term post-college plans.

The study by Bailey, Burrell, and Ware provides an ideal set of data to examine the research questions posed by this study. High achieving students at an ultra-prestigious university are being examined. In principle, the students entering an institution such as Harvard all have the ability to persist in STEM majors. However, the factors that play into this unique set of students' non-persistence remain relatively unexamined. Therefore, using the data collected by Bailey, Burrell and Ware, this study will examine three main potential predictors of student persistence in STEM majors: demographic factors, measured by minority status and gender; preuniversity matriculation achievement, as measured by scores on both mathematics and verbal sections of the SAT standardized test; and post-university matriculation achievement, as measured by the average grade point average in both STEM and non-STEM courses during students' first year of study. The longitudinal aspect of the data set also provides an opportunity to examine the issue of STEM major persistence in a new way: by using discrete-time survival analysis to investigate not only the chance of leaving a STEM major, but examining whether certain factors play a role in both if and when a student does not persist in a STEM major.

As outlined by Singer \& Willett (2003), survival analysis is appropriate when a study has three methodological features (p. 310): A target event, a beginning of time, and a metric for clocking time. In this study, the target event is a change from a STEM major to a non-STEM major. Again, the purpose of this study is to examine changes in major, not dropout (or stopout) from the university as a whole. The initial starting point, or the beginning of time, is the first wave of data collection in the data set: the data collected about intended major in the summer before matriculation at Harvard. As a metric for clocking time, this study uses the time metric of the year of study. Therefore, the study has four additional waves of STEM major persistence, one at the beginning of the freshman, sophomore, junior and senior year.

The data on major in the data set did not distinguish majors as STEM or non-STEM, instead listing each major individually without categorizing it as such. Therefore, how to define a STEM major for this study was essential to examine our research questions. While some studies find that not all STEM majors are created equal regarding student persistence, particularly females in engineering (e.g., Min et al., 2011), others find no significant differences in persistence between the physical sciences and life sciences (King, 2016). To better understand STEM persistence, we cast a wide net and define STEM majors as biological and physical sciences, mathematics, computer science, engineering, and premedical studies.

As previously mentioned, the first wave of data from Bailey, Burrell and Ware's study was collected pre-matriculation and asked students to indicate three majors they were considering. For this study, students were categorized as intending to major in STEM if they had indicated that at least one of their top two choices of major was a STEM major, as defined by the researcher using the definition above. The data collected in the second wave, in November of the freshman year, also asked students to list the three top choices of major. This question about top major choices is because students do not have to declare their major at this point of study. The same method was used to define an intended STEM major at this wave as well: if a STEM major was listed as one of the top two choices. The major indicated in the final three waves are the declared majors of the students in the sample and therefore are coded into STEM and Non-STEM majors for this study.

The minority variable in the study is defined based on the self-reported race on the questionnaire during the first wave of data collection. While the role of race in STEM persistence has been well examined, the results have varied, depending on the definition of minority versus majority group. Several studies (e.g., Griffith, 
2010) define minority status as non-white racial groups, while others (e.g., Min et al., 2011) define minority status as ethnic groups that are significantly underrepresented in high levels of engineering and science, usually excluding Asians from their definition of minority status. In this study, due to our broader definition of STEM majors, we define minority status as white versus other ethnic groups.

The variables defining pre-university matriculation achievement as math and verbal SAT scores are broken down into two groups. This study is particularly interested in seeing differences between the highestachieving students and other students. Therefore, we define our highest achieving group as students who have scored 700 or greater on the math section of the SAT. Additionally, to determine if there are survival and hazard probability differences between students with high scores on the math versus the verbal SAT, we also examine students with 700 or greater on the verbal section of the SAT. For our measures of post-matriculation achievement, we use a continuous measure of both STEM and non-STEM grade point average during students' first year of study. Since students may still be "undeclared" during their first year of study at Harvard, the grade point average in STEM versus non-STEM classes may have a strong impact in a change in intention to declare a STEM major.

Examining the total sample $(\mathrm{N}=300), 95$ students in the sample are found not to intend to major in STEM at the point before matriculation. Therefore, the total number of students investigated in this study is 205. For minority status, approximately 48 percent of the sample was white $(\mathrm{n}=98)$ and approximately 22 percent were minorities $(n=44)$. Another 30 percent did not indicate their race on the questionnaire $(n=63)$. The sample was approximately 52 percent female $(n=106)$ and 48 percent male $(n=99) .56$ percent of students scored 700 or higher on the math SAT $(\mathrm{n}=115)$, while only 38 percent scored 700 or higher on the verbal SAT $(n=77)$. Of the sample of 205 students intending to major in a STEM field before matriculation, only 68 students remain in a STEM major at the last wave of data collection, during the fall semester of their senior year. Our event of interest (departure from a STEM major) is experienced by 137 students, or approximately 67 percent of the sample.

\section{Results \\ Background}

Table 1.

Bivariate correlations of variables used in the discrete-time survival analysis

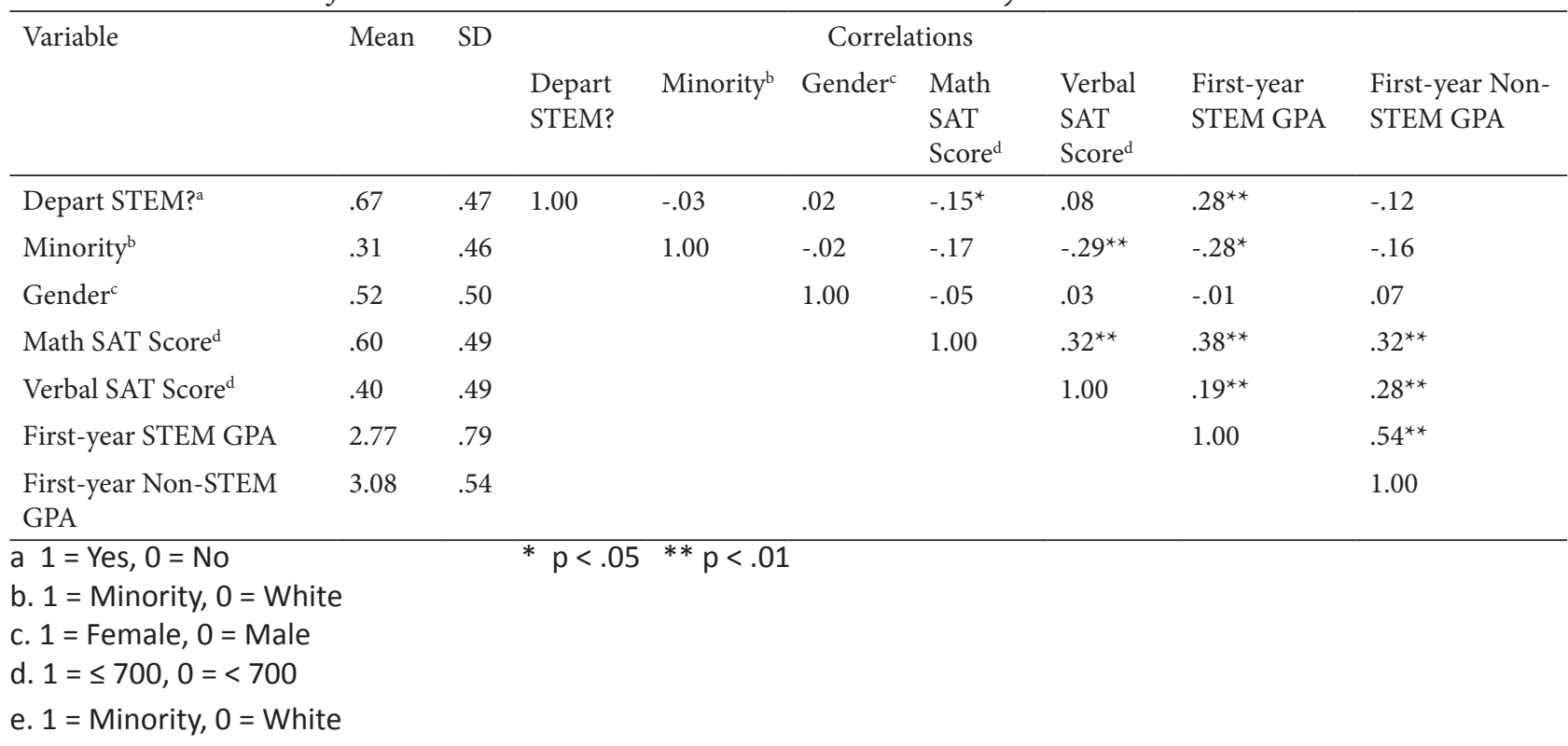


Table 1 shows the Pearson correlation coefficients computed among the six predictors with STEM major departure. The results of these correlational analyses indicated that two of the six predictors were significantly correlated with STEM major departure. Math SAT score was negative and significantly correlated with STEM major departure, $\mathrm{r}(203)=-.15, \mathrm{p}<.05$. First-year STEM GPA was significantly, but positively correlated with STEM major departure, $\mathrm{r}(203)=.28, \mathrm{p}<.01$; and negatively with minority status, $\mathrm{r}(203)=-.28, \mathrm{p}<.01$. To note, STEM major departure was not significantly correlated with either minority status, $r(203)=-.03, \mathrm{p}>.05$; or with gender, $\mathrm{r}(203)=.02, \mathrm{p}>.05$.

Discrete-time survival analysis was conducted using SPSS statistical software package. Life tables were calculated with the SURVIVAL program using a "person-level" data set (Singer \& Willet, 2003), while a "person-period" data set was used with the LOGISTIC REGRESSION program to examine four discrete-time hazard models with six individual covariates: minority status, gender, math SAT achievement level, verbal SAT achievement level, first-year STEM grade point average, and first-year non-STEM grade point average. Four individual models were defined as follows:

$$
\begin{aligned}
& \text { Model A: Logit } h(t j)=[\alpha 1 \mathrm{D} 1+\alpha 2 \mathrm{D} 2+\alpha 3 \mathrm{D} 3+\alpha 4 \mathrm{D} 4] \\
& \text { Model B: Logit } h(\mathrm{tj})=[\alpha 1 \mathrm{D} 1+\alpha 2 \mathrm{D} 2+\alpha 3 \mathrm{D} 3+\alpha 4 \mathrm{D} 4]+\beta 1 \text { minority }+\beta 2 \text { gender } \\
& \text { Model C: } \operatorname{Logit} \mathrm{h}(\mathrm{tj})=[\alpha 1 \mathrm{D} 1+\alpha 2 \mathrm{D} 2+\alpha 3 \mathrm{D} 3+\alpha 4 \mathrm{D} 4]+\beta 1 \text { minority }+\beta 2 \text { gender }+ \\
& \beta 3 \text { mathSAT }+\beta 4 \text { verbalSAT } \\
& \text { Model D: Logit } \mathrm{h}(\mathrm{tj})=[\alpha 1 \mathrm{D} 1+\alpha 2 \mathrm{D} 2+\alpha 3 \mathrm{D} 3+\alpha 4 \mathrm{D} 4]+\beta 1 \text { minority }+\beta 2 \text { gender }+ \\
& \beta 3 \text { mathSAT }+\beta 4 \text { verbalSAT }+\beta 5 \text { freshmanSTEMgpa }+\beta 6 \text { freshmanNON-STEMgpa }
\end{aligned}
$$

Where $\mathrm{Dj}$ is the time indicator at time period $\mathrm{j}$, and $\mathrm{h}(\mathrm{t} \mathrm{j})$ is the probability that individual $\mathrm{i}$ experiences the event in time period $\mathrm{j}$ (Singer \& Willett, 2003).

Model A explored only the main effects of the semester time indicators, which serves as the baseline for comparisons. Model B adds the demographic characteristics of minority status and gender to the time-only indicators. Model C includes the pre-matriculation achievement variables of math SAT and verbal SAT to the other variables. Finally, Model D adds the post-matriculation variables of first-year STEM GPA and first-year

\begin{tabular}{|c|c|c|c|c|c|c|c|}
\hline \multirow[b]{2}{*}{ Year } & \multicolumn{3}{|l|}{ Number who... } & \multirow[b]{2}{*}{$\begin{array}{l}\text { Hazard Prob- } \\
\text { ability }\end{array}$} & \multirow[b]{2}{*}{$\begin{array}{l}\text { Survival } \\
\text { Probability }\end{array}$} & \multirow[b]{2}{*}{ Odds } & \multirow[b]{2}{*}{ Logit(Hazard) } \\
\hline & $\begin{array}{l}\text { Were at risk (still } \\
\text { in STEM major) at } \\
\text { the beginning of } \\
\text { the year }\end{array}$ & $\begin{array}{l}\text { Left STEM } \\
\text { major during } \\
\text { year }\end{array}$ & $\begin{array}{l}\text { Were censored } \\
\text { at the end of } \\
\text { the year }\end{array}$ & & & & \\
\hline 0 & 205 & 0 & 0 & 0 & 1 & 0 & \\
\hline 1 & 205 & 24 & 0 & 0.117 & 0.882 & 0.132 & -2.020 \\
\hline 2 & 181 & 42 & 0 & 0.232 & 0.678 & 0.302 & -1.197 \\
\hline 3 & 139 & 52 & 0 & 0.374 & 0.480 & 0.597 & -0.514 \\
\hline 4 & 87 & 19 & 68 & 0.218 & 0.489 & 0.279 & -1.275 \\
\hline
\end{tabular}
non-STEM GPA to complete the model. The change statistics, -2LL (Log Likelihood) of the baseline Model A and Models B, C, and D indicate if a significant difference exists between the models.

Discrete-Time Survival Analysis Results

Table 2.

Life table survival and hazard estimates for entire sample of students beginning as intended STEM majors

Table 2 summarizes the overall life table estimates by interval for the entire sample, including the number of students at risk (still in STEM majors) at the beginning of each interval, number of students experiencing the event of interest (departure from a STEM major) during that interval, hazard probability and survival 
probability during the interval, odds of event occurrence during the interval, and the logit(hazard) function. The censored students are the individuals that did not experience the event. The only students censored in this study are the students remaining in STEM majors in their senior year of study; hence only censored cases exist in the fourth year (or fifth wave).

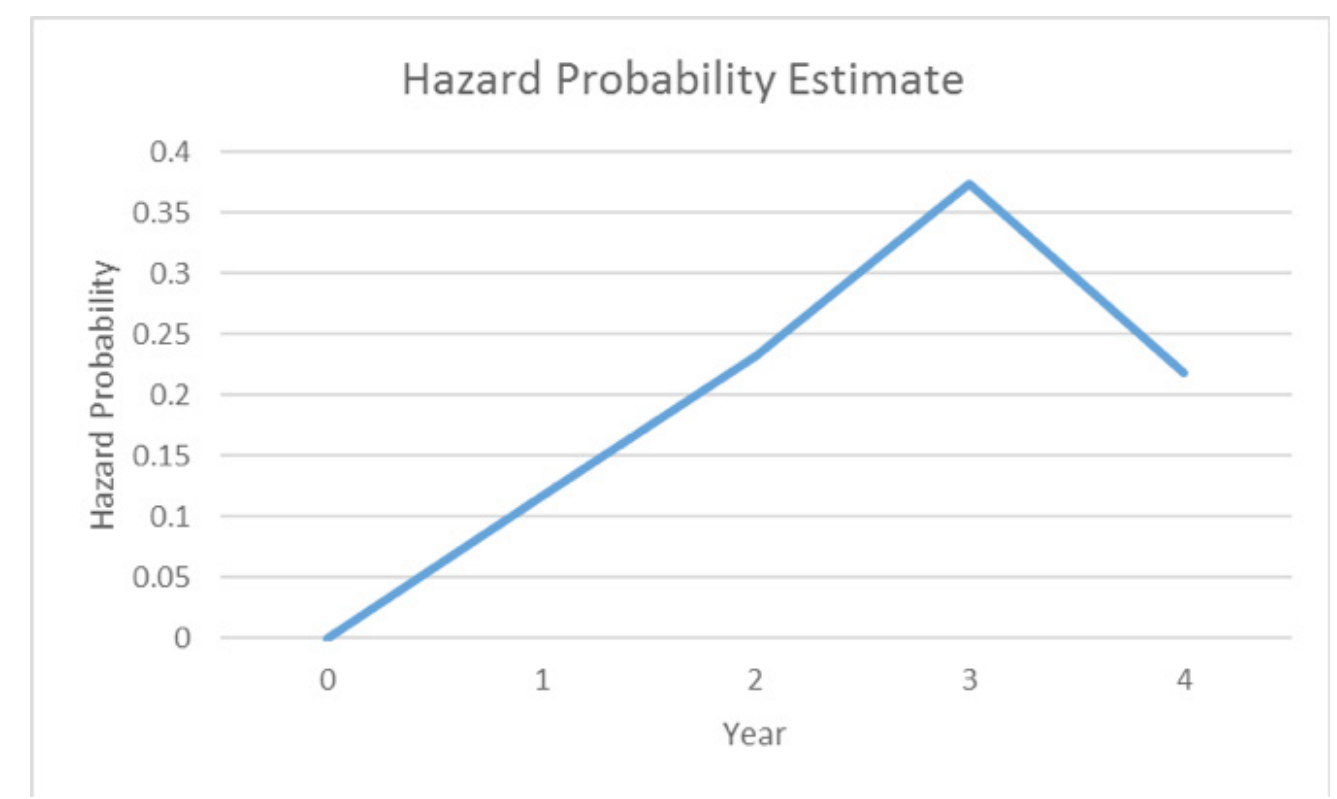

Figure 1. Hazard probability estimate for entire sample of students beginning as intended STEM majors.

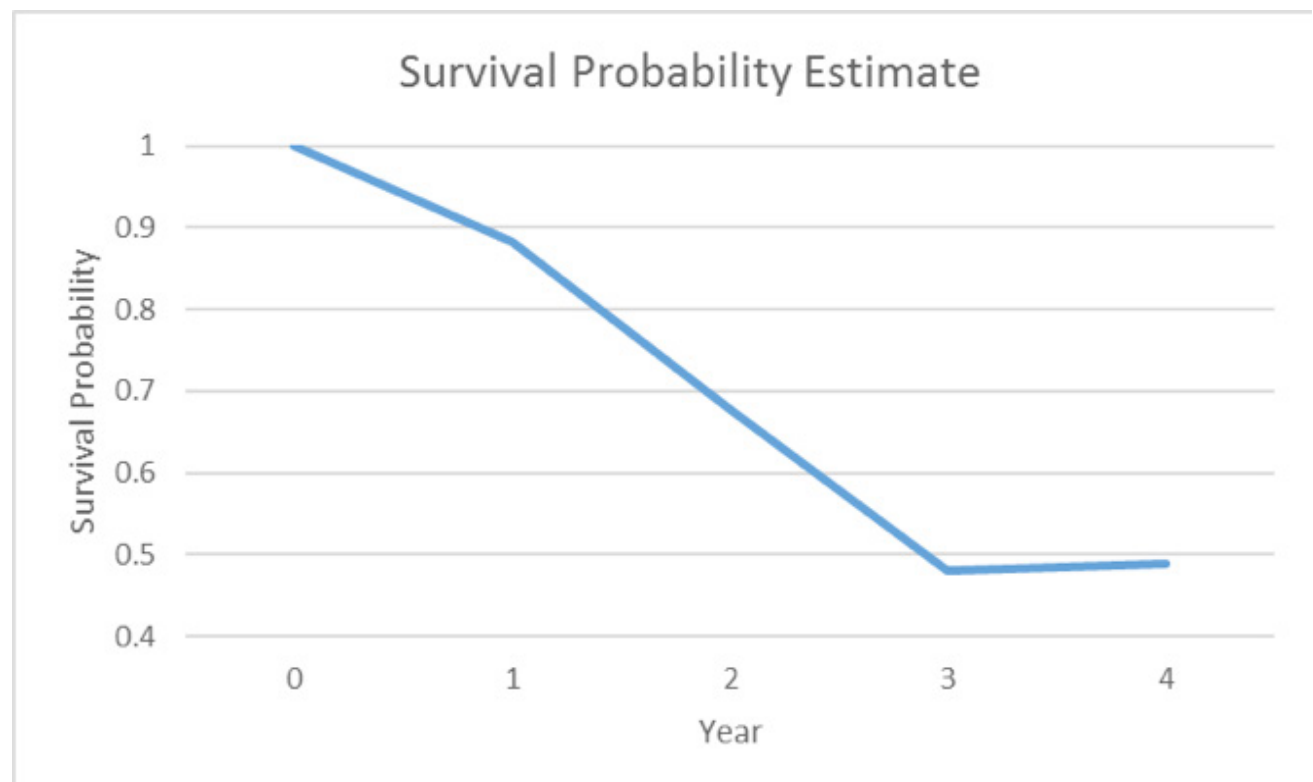

Figure 2. Survival probability estimate for entire sample of students beginning as intended STEM majors.

Figure 1 plots the hazard probability estimate for the entire sample. The hazard of leaving a STEM major increases throughout the undergraduate career until a peak at the beginning of the junior year $(j=3)$, before decreasing at the last time period. The corresponding survival probability estimates are shown in Figure 2 . The survival probability demonstrates a decreasing trend up until the junior year, then remains stable through the senior year. 
Table 3.

Life table survival and hazard estimates for sample of students beginning as intended STEM majors, by minority status

\begin{tabular}{|c|c|c|c|c|c|c|c|}
\hline \multicolumn{8}{|c|}{ White } \\
\hline \multirow[b]{2}{*}{ Year } & \multicolumn{3}{|l|}{ Number who... } & \multirow[b]{2}{*}{ Hazard Probability } & \multirow[b]{2}{*}{$\begin{array}{l}\text { Survival } \\
\text { Probability }\end{array}$} & \multirow[b]{2}{*}{ Odds } & \multirow[b]{2}{*}{ Logit(Hazard) } \\
\hline & $\begin{array}{l}\text { Were at risk (still in } \\
\text { STEM major) at the } \\
\text { beginning of the } \\
\text { year }\end{array}$ & $\begin{array}{l}\text { Left STEM } \\
\text { major } \\
\text { during year }\end{array}$ & $\begin{array}{l}\text { Were } \\
\text { censored at } \\
\text { the end of } \\
\text { the year }\end{array}$ & & & & \\
\hline 0 & 98 & 0 & 0 & 0 & 1 & 0 & \\
\hline 1 & 98 & 12 & 0 & 0.122 & 0.877 & 0.139 & -1.969 \\
\hline 2 & 86 & 27 & 0 & 0.314 & 0.602 & 0.457 & -0.781 \\
\hline 3 & 59 & 20 & 0 & 0.339 & 0.453 & 0.512 & -0.667 \\
\hline 4 & 39 & 6 & 33 & 0.153 & 0.559 & 0.181 & -1.704 \\
\hline \multicolumn{8}{|c|}{ Minority } \\
\hline & \multicolumn{3}{|l|}{ Number who... } & \multirow[b]{2}{*}{ Hazard Probability } & \multirow[b]{2}{*}{$\begin{array}{l}\text { Survival } \\
\text { Probability }\end{array}$} & \multirow[b]{2}{*}{ Odds } & \multirow[b]{2}{*}{ Logit(Hazard) } \\
\hline Year & $\begin{array}{l}\text { Were at risk (still in } \\
\text { STEM major) at the } \\
\text { beginning of the } \\
\text { year }\end{array}$ & $\begin{array}{l}\text { Left STEM } \\
\text { major } \\
\text { during year }\end{array}$ & $\begin{array}{l}\text { Were cen- } \\
\text { sored at the } \\
\text { end of the } \\
\text { year }\end{array}$ & & & & \\
\hline 0 & 44 & 0 & 0 & 0 & 1 & 0 & \\
\hline 1 & 44 & 6 & 0 & 0.136 & 0.863 & 0.157 & -1.845 \\
\hline 2 & 38 & 4 & 0 & 0.105 & 0.772 & 0.117 & -2.140 \\
\hline 3 & 34 & 12 & 0 & 0.352 & 0.578 & 0.545 & -0.606 \\
\hline 4 & 22 & 6 & 16 & 0.272 & 0.470 & 0.375 & -0.980 \\
\hline
\end{tabular}

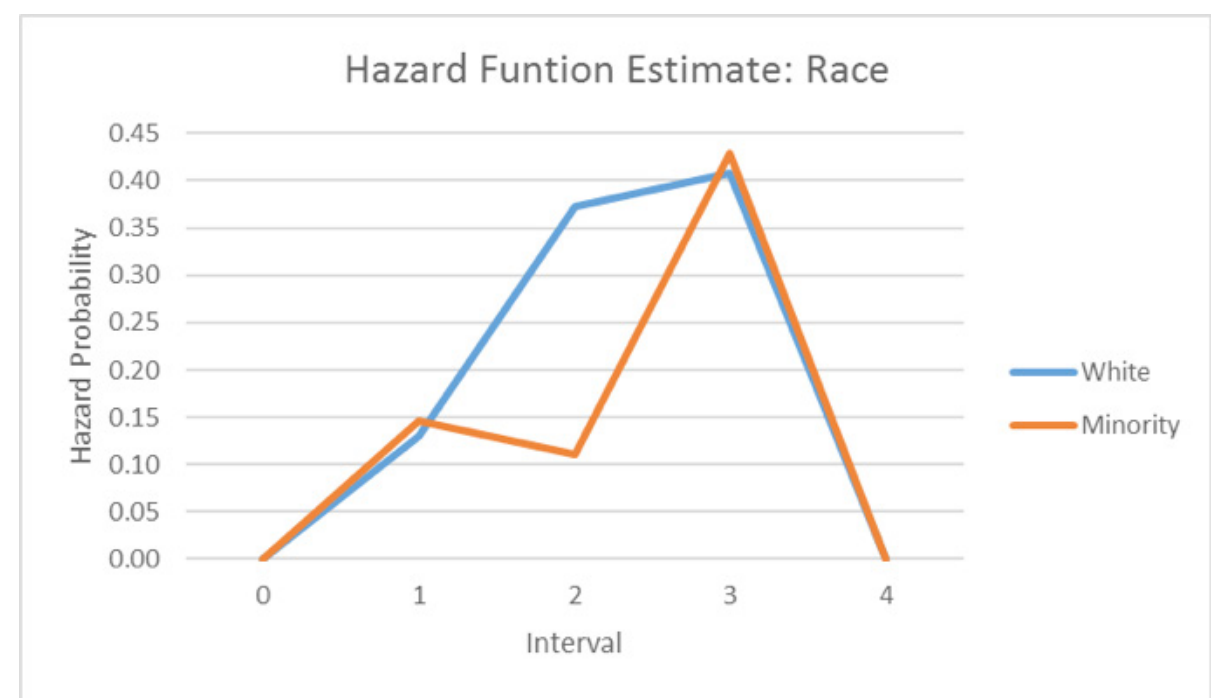

Figure 3. Hazard probability estimate for sample of students beginning as intended STEM majors, by minority status. 


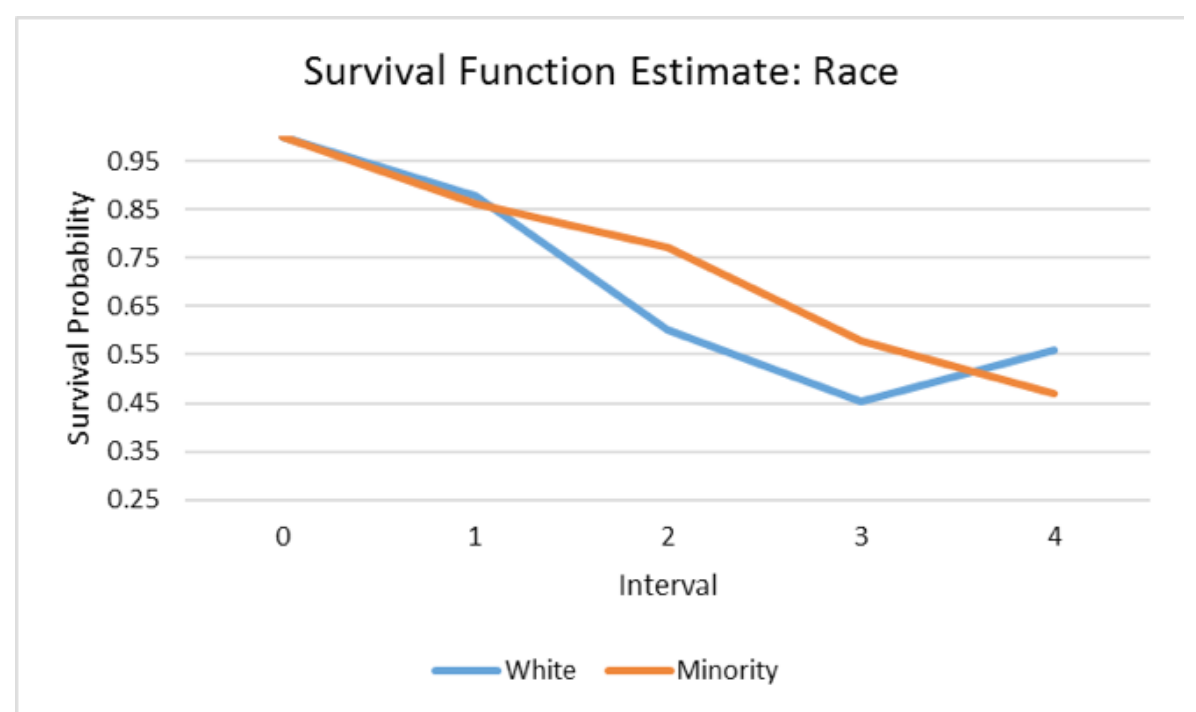

Figure 4. Survival probability estimate for sample of students beginning as intended STEM majors, by minority status.

Table 3 shows the life table for the two minority status groups studied: white students and students of other ethnicities. While the hazard probability increases at similar rates for white and minority students from pre-matriculation STEM major intention to first-semester STEM major departure, we see a large degree of difference in hazard probability at the beginning of the sophomore year. The difference in hazard is highlighted in Figure 3. The hazard probability for minority students at the beginning of the sophomore year is approximately 10.5 percent, while for white students it is 31.4 percent. The hazard rate evens out between minority status groups at the beginning of the junior year, which is also at its highest for both groups. Figure 4 shows the corresponding survival probability, showing the higher survival probability for minority students through year two and three. Interestingly, the probability of persisting in a STEM major for minority students is less in the final year of study, potentially illustrating that minority students may be more likely to persist up until the fourth year, but may experience a bottleneck effect that this point in their studies. 
Table 4.

Life table survival and hazard estimates for entire sample of students beginning as intended STEM majors, by gender

\begin{tabular}{|c|c|c|c|c|c|c|c|}
\hline \multicolumn{8}{|l|}{ Male } \\
\hline \multirow[b]{2}{*}{ Year } & \multicolumn{3}{|l|}{ Number who... } & \multirow[b]{2}{*}{$\begin{array}{l}\text { Hazard } \\
\text { Probability }\end{array}$} & \multirow[b]{2}{*}{$\begin{array}{l}\text { Survival } \\
\text { Probability }\end{array}$} & \multirow[b]{2}{*}{ Odds } & \multirow[b]{2}{*}{ Logit(Hazard) } \\
\hline & $\begin{array}{l}\text { Were at risk (still in STEM } \\
\text { major) at the beginning of } \\
\text { the year }\end{array}$ & $\begin{array}{l}\text { Left STEM } \\
\text { major } \\
\text { during year }\end{array}$ & $\begin{array}{l}\text { Were censored } \\
\text { at the end of the } \\
\text { year }\end{array}$ & & & & \\
\hline 0 & 99 & 0 & 0 & 0 & 1 & 0 & \\
\hline 1 & 99 & 10 & 0 & 0.101 & 0.899 & 0.112 & -2.186 \\
\hline 2 & 89 & 14 & 0 & 0.157 & 0.757 & 0.186 & -1.678 \\
\hline 3 & 75 & 26 & 0 & 0.346 & 0.550 & 0.530 & -0.633 \\
\hline 4 & 49 & 15 & 34 & 0.306 & 0.453 & 0.441 & -0.818 \\
\hline \multicolumn{8}{|c|}{ Female } \\
\hline & \multicolumn{7}{|l|}{ Number who... } \\
\hline Year & $\begin{array}{l}\text { Were at risk (still in STEM } \\
\text { major) at the beginning of } \\
\text { the year }\end{array}$ & $\begin{array}{l}\text { Left STEM } \\
\text { major } \\
\text { during year }\end{array}$ & $\begin{array}{l}\text { Were censored } \\
\text { at the end of the } \\
\text { year }\end{array}$ & $\begin{array}{l}\text { Hazard } \\
\text { Probability }\end{array}$ & $\begin{array}{l}\text { Survival } \\
\text { Probability }\end{array}$ & Odds & Logit(Hazard) \\
\hline 0 & 106 & 0 & 0 & 0 & 1 & 0 & \\
\hline 1 & 106 & 14 & 0 & 0.132 & 0.867 & 0.152 & -1.882 \\
\hline 2 & 92 & 28 & 0 & 0.304 & 0.603 & 0.437 & -0.826 \\
\hline 3 & 64 & 26 & 0 & 0.406 & 0.413 & 0.684 & -0.379 \\
\hline 4 & 38 & 4 & 34 & 0.105 & 0.531 & 0.117 & -2.140 \\
\hline
\end{tabular}

Table 4 presents the life table survival and hazard estimates for the students in the sample, comparing by gender. As highlighted in Figure 5 and 6 below, the hazard probability for males is lower than for females through the beginning of the junior year, with the beginning of the sophomore year showing a larger hazard for females than for males. The survival probability demonstrates that, at the beginning of the senior year, the survival probability is greater for females than for males. The hazard probability is great for males than for females at the beginning of the senior year. While the hazard appears greater for females throughout their undergraduate career, the females who persist to the senior year appear to have a higher survival probability than their male classmates.

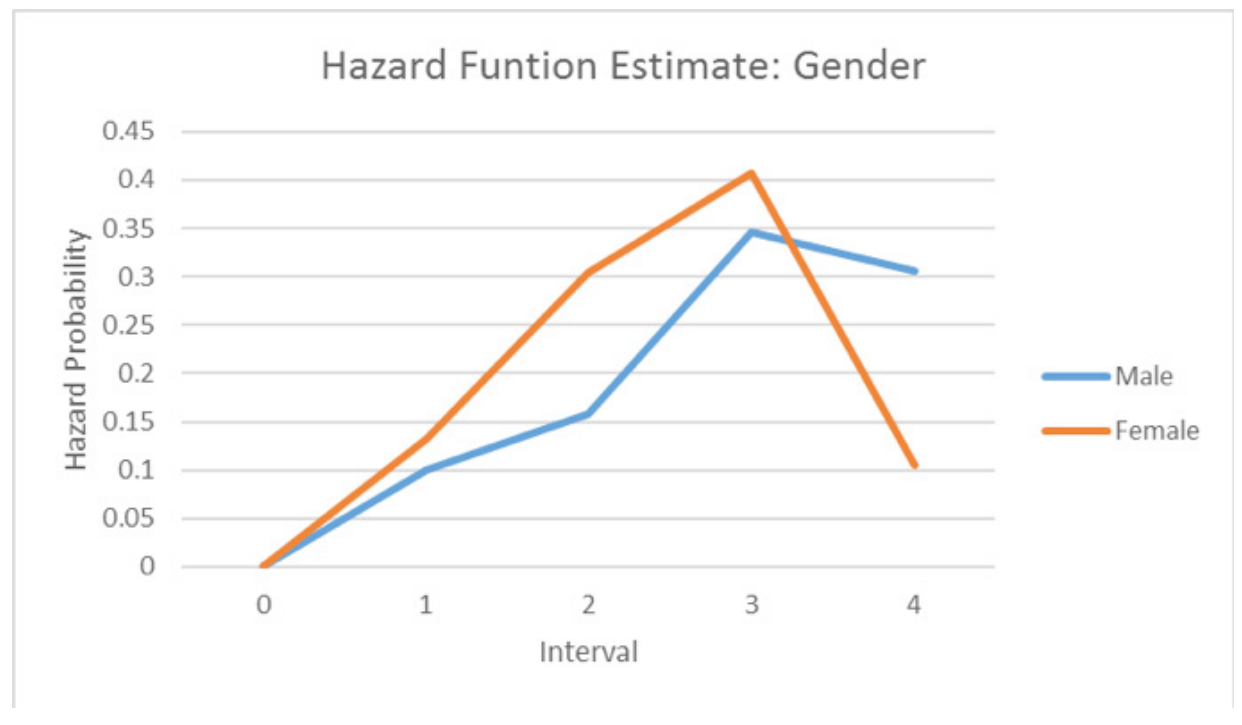

Figure 5. Hazard probability estimate for sample of students beginning as intended STEM majors, by gender. 


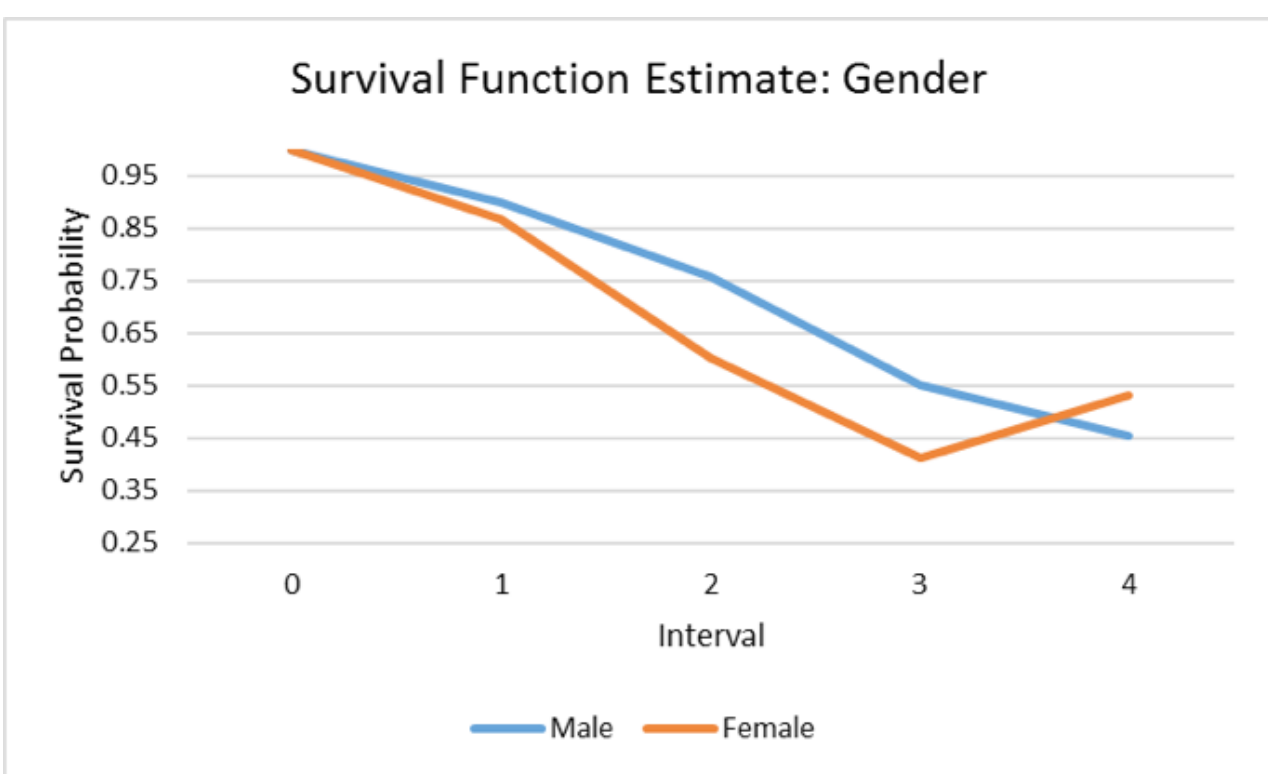

Figure 6. Survival probability estimate for sample of students beginning as intended STEM majors, by gender.

Table 5.

Life table survival and hazard estimates for entire sample of students beginning as intended STEM majors, by level of achievement on the Mathematics SAT test

\begin{tabular}{|c|c|c|c|c|c|c|c|}
\hline \multicolumn{8}{|l|}{ Low } \\
\hline \multirow[b]{2}{*}{ Year } & \multicolumn{3}{|l|}{ Number who... } & \multirow[b]{2}{*}{$\begin{array}{l}\text { Hazard } \\
\text { Probability }\end{array}$} & \multirow[b]{2}{*}{$\begin{array}{l}\text { Survival } \\
\text { Probability }\end{array}$} & \multirow[b]{2}{*}{ Odds } & \multirow[b]{2}{*}{ Logit(Hazard) } \\
\hline & $\begin{array}{l}\text { Were at risk (still in STEM } \\
\text { major) at the beginning of } \\
\text { the year }\end{array}$ & $\begin{array}{l}\text { Left STEM } \\
\text { major } \\
\text { during year }\end{array}$ & $\begin{array}{l}\text { Were censored } \\
\text { at the end of } \\
\text { the year }\end{array}$ & & & & \\
\hline 0 & 77 & 0 & 0 & 0 & 1 & 0 & \\
\hline 1 & 77 & 13 & 0 & 0.168 & 0.831 & 0.203 & -1.593 \\
\hline 2 & 64 & 18 & 0 & 0.281 & 0.597 & 0.391 & -0.938 \\
\hline 3 & 46 & 21 & 0 & 0.456 & 0.390 & 0.840 & -0.174 \\
\hline 4 & 25 & 6 & 19 & 0.240 & 0.413 & 0.315 & -1.153 \\
\hline \multicolumn{8}{|l|}{ High } \\
\hline & \multicolumn{3}{|l|}{ Number who... } & & & & \\
\hline Year & $\begin{array}{l}\text { Were at risk (still in STEM } \\
\text { major) at the beginning of } \\
\text { the year }\end{array}$ & $\begin{array}{l}\text { Left STEM } \\
\text { major } \\
\text { during year }\end{array}$ & $\begin{array}{l}\text { Were censored } \\
\text { at the end of } \\
\text { the year }\end{array}$ & $\begin{array}{l}\text { Hazard } \\
\text { Probability }\end{array}$ & $\begin{array}{l}\text { Survival } \\
\text { Probability }\end{array}$ & Odds & Logit(Hazard) \\
\hline 0 & 115 & 0 & 0 & 0 & 1 & 0 & \\
\hline 1 & 115 & 11 & 0 & 0.095 & 0.904 & 0.105 & -2.24 \\
\hline 2 & 104 & 23 & 0 & 0.221 & 0.704 & 0.283 & -1.258 \\
\hline 3 & 81 & 23 & 0 & 0.284 & 0.557 & 0.396 & -0.924 \\
\hline 4 & 58 & 13 & 45 & 0.224 & 0.555 & 0.288 & -1.241 \\
\hline
\end{tabular}

Table 5 and 6 and the corresponding hazard and survival probability plots show the difference in STEM major persistence for students with SAT scores on the math and verbal sections of the SAT of 700 or higher with those students with lower scores. Here, we see an intriguing trend: students with high achievement on the SAT in math have higher survival probabilities and lower hazard probabilities throughout all periods of 
undergraduate study, with the highest hazard rate for students with lower SAT scores at the beginning of the junior year. However, the opposite is true for student achievement on the verbal SAT. While the hazard rate is similar at the first time period (beginning of freshman year), subsequent semesters show a greater hazard probability and lower survival probability for students with the highest verbal SAT scores over students with lower verbal SAT scores.

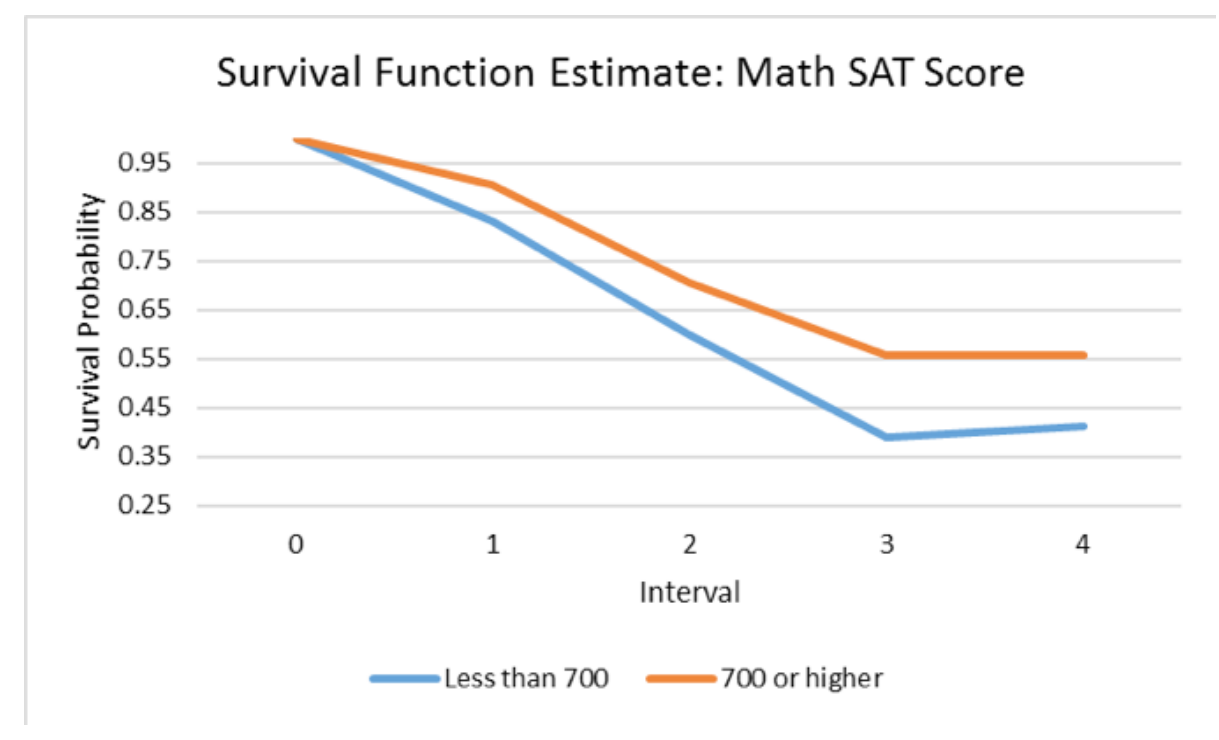

Figure 7. Survival probability estimate for sample of students beginning as intended STEM majors, by level of achievement on the Mathematics SAT test.

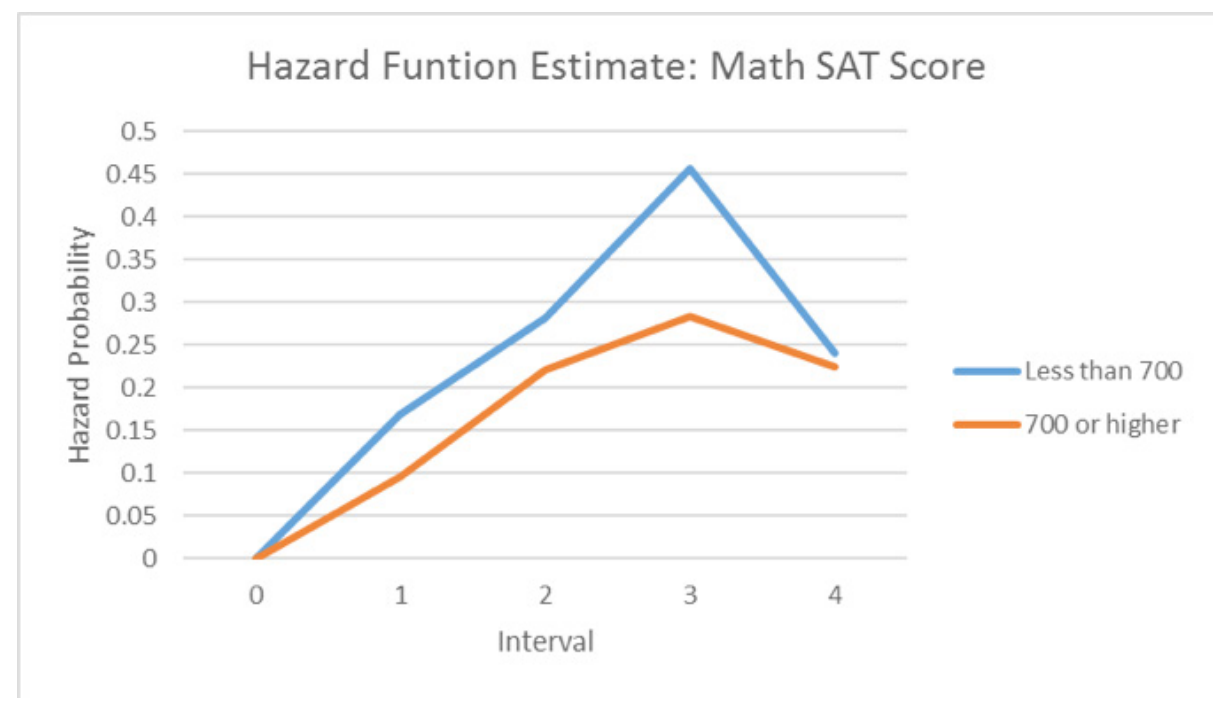

Figure 8. Hazard probability estimate for sample of students beginning as intended STEM majors, by level of achievement on the Mathematics SAT test. 
Table 6.

Life table survival and hazard estimates for entire sample of students beginning as intended STEM majors, by level of achievement on the Verbal SAT test

\begin{tabular}{|c|c|c|c|c|c|c|c|}
\hline \multicolumn{8}{|l|}{ Low } \\
\hline \multirow[b]{2}{*}{ Year } & \multicolumn{3}{|l|}{ Number who... } & \multirow[b]{2}{*}{$\begin{array}{l}\text { Hazard Prob- } \\
\text { ability }\end{array}$} & \multirow[b]{2}{*}{$\begin{array}{l}\text { Survival } \\
\text { Probability }\end{array}$} & \multirow[b]{2}{*}{ Odds } & \multirow[b]{2}{*}{ Logit(Hazard) } \\
\hline & $\begin{array}{l}\text { Were at risk (still in STEM } \\
\text { major) at the beginning of } \\
\text { the year }\end{array}$ & $\begin{array}{l}\text { Left STEM } \\
\text { major } \\
\text { during year }\end{array}$ & $\begin{array}{l}\text { Were censored } \\
\text { at the end of } \\
\text { the year }\end{array}$ & & & & \\
\hline 0 & 115 & 0 & 0 & 0 & 1 & 0 & \\
\hline 1 & 115 & 16 & 0 & 0.139 & 0.860 & 0.161 & -1.822 \\
\hline 2 & 99 & 20 & 0 & 0.202 & 0.687 & 0.253 & -1.373 \\
\hline 3 & 79 & 26 & 0 & 0.329 & 0.535 & 0.490 & -0.712 \\
\hline 4 & 53 & 11 & 42 & 0.207 & 0.531 & 0.261 & -1.339 \\
\hline \multicolumn{8}{|l|}{ High } \\
\hline & \multicolumn{3}{|l|}{ Number who... } & \multirow[b]{2}{*}{$\begin{array}{l}\text { Hazard Prob- } \\
\text { ability }\end{array}$} & \multirow[b]{2}{*}{$\begin{array}{l}\text { Survival } \\
\text { Probability }\end{array}$} & \multirow[b]{2}{*}{ Odds } & \multirow[b]{2}{*}{ Logit(Hazard) } \\
\hline Year & $\begin{array}{l}\text { Were at risk (still in STEM } \\
\text { major) at the beginning of } \\
\text { the year }\end{array}$ & $\begin{array}{l}\text { Left STEM } \\
\text { major } \\
\text { during year }\end{array}$ & $\begin{array}{l}\text { Were censored } \\
\text { at the end of } \\
\text { the year }\end{array}$ & & & & \\
\hline 0 & 77 & 0 & 0 & 0 & 1 & 0 & \\
\hline 1 & 77 & 8 & 0 & 0.103 & 0.896 & 0.115 & -2.154 \\
\hline 2 & 69 & 21 & 0 & 0.304 & 0.623 & 0.437 & -0.826 \\
\hline 3 & 48 & 18 & 0 & 0.375 & 0.434 & 0.600 & -0.510 \\
\hline 4 & 30 & 8 & 22 & 0.266 & 0.458 & 0.363 & -1.011 \\
\hline
\end{tabular}

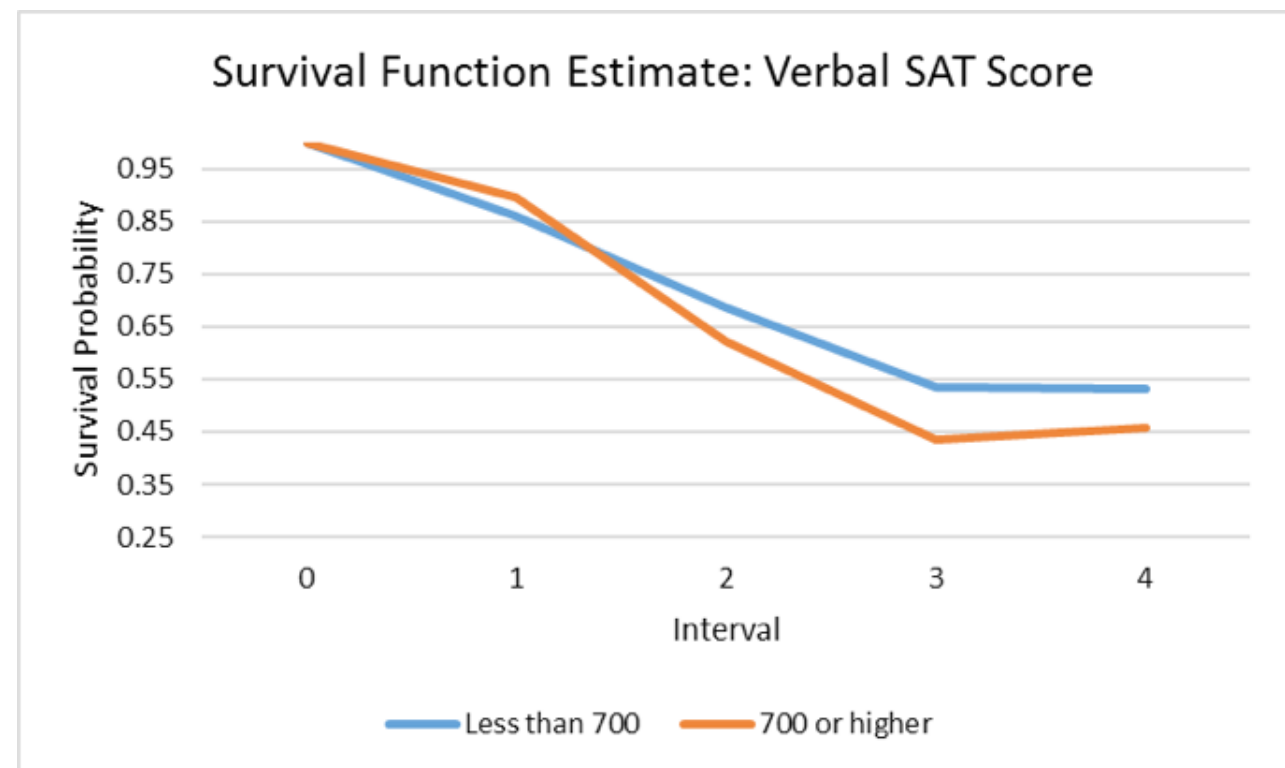

Figure 9. Survival probability estimate for sample of students beginning as intended STEM majors, by level of achievement on the Verbal SAT test. 


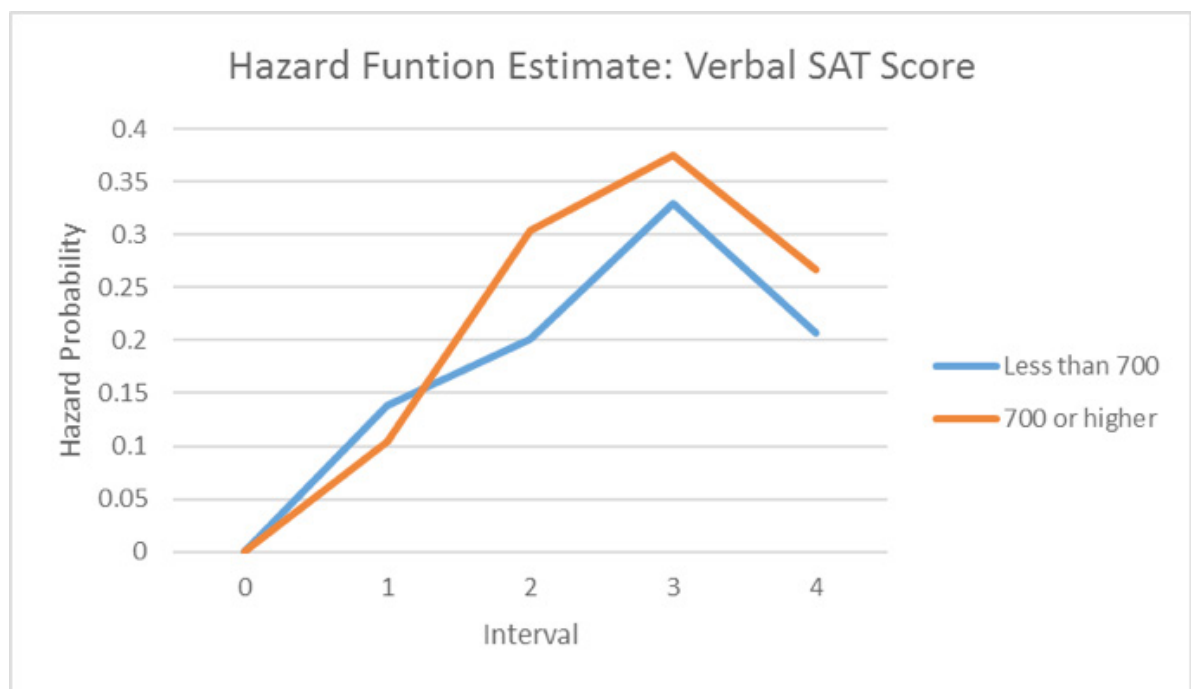

Figure 10. Hazard probability estimate for sample of students beginning as intended STEM majors, by level of achievement on the Verbal SAT test.

Table 7 highlights the results of the parameter estimates obtained from the fitting of the four discretetime hazard models to the time to departure from STEM major data, as defined earlier. Model A does not include any substantive predictors, so the baseline is the entire sample of students (Singer \& Willett, 2003). We see that the parameter estimates for the time period dummy variables increases up until time period 3, or junior year $(B=-.676$, S.E. .224, $\operatorname{Exp}(B)=.508 \mathrm{p}<.01)$, then decreases again at time period 4 , or senior year $(B$ $=-1.494$, S.E. $.334, \operatorname{Exp}(\mathrm{B})=.224 \mathrm{p}<.001$.

Model $\mathrm{B}$ adds the demographic variables of minority status and gender to the time indicators. In model $B$, we do not see significant effects of either minority status $(B=-.166$, S.E. .264, Exp $(B)=.847$ p $>.05)$ or gender $(\mathrm{B}=.281$, S.E. . 249 , $\operatorname{Exp}(\mathrm{B})=1.325 \mathrm{p}>.05)$.

Model $\mathrm{C}$ adds the variables of pre-college achievement, specifically high-scoring students on math and verbal SATs. The results suggest that the odds of departure from STEM majors are significantly lower for students scoring 700 or higher on the math SAT, B = -.687, S.E. .288, $\operatorname{Exp}(B)=.503, p<.01$. The odds of switching from a STEM major to a non-STEM major for the highest scoring students on the math SAT are .503 times that of students scoring less than 700. Alternatively, the odds of departure from STEM majors are greater for students who scored 700 or higher on the verbal SAT test; B $=.607$, S.E. $=.293$, Exp $(B)=1.836, p<.05$. The estimated odds of switching from a STEM major to a non-stem major are about 1.8 times that of students scoring less than 700 .

Continuing to the full model (Model D), the post-enrollment achievement measures of first-year GPA in STEM and non-STEM subjects are added to the previous model. The odds of departure from a STEM major are found to be significantly lower for students with higher STEM grades in their first year of study; B $=-.467$, S.E. $=.200, \operatorname{Exp}(B)=.627, p<.05$. For every one-point increase in freshman STEM GPA, the estimated odds of switching from a STEM major to a non-STEM major are .627 times that of lower achieving students. First-year non-STEM GPA is not found to be significant, $B=.016$, S.E. $=.264$, Exp $(B)=1.016, p>.05$.

\section{Discussion and Conclusion}

Despite the great breadth of research on university persistence and factors related to dropout from institutions of higher education in the United States, there has been relatively little attention devoted toward investigations into factors related to changes in major during a student's undergraduate career. Additionally, 
while there has been some research on dropout from STEM majors, studies are often related to certain specific disciplines, such as engineering (Min et al., 2011) and often include both changes in major and dropout/stopout. Further, studies lack focus on high-achieving students. While some studies have found significant results based on high-achievement (Ware \& Lee, 1988), this study seeks to focus on this under-researched group of students.

Discrete-time survival analysis was used to analyze the rate of students changing majors from STEM fields to non-STEM fields using longitudinal data collected from Harvard University. This dataset provides an opportunity to examine factors related to STEM major persistence specifically in the context of the highestachieving students at prestigious universities. What factors lead to a high probability of departure from STEM majors, and when are these departures most likely to occur? These are the questions this study seeks to answer.

Examining the data on STEM major persistence, we see a trend across all variables studied. Hazard rates are highest at time period 3, or the beginning of the junior year of study. However, the hazard probability estimates do differ among different groups at other time periods, particularly in the case of minority group status

Table 7.

Results of fitting four models of discrete-time survival analysis to year of departure from STEM majors

\begin{tabular}{|c|c|c|c|c|c|c|c|c|c|c|c|c|}
\hline \multirow[b]{2}{*}{ Predictor(s) } & \multicolumn{3}{|l|}{ Model A } & \multicolumn{3}{|l|}{ Model B } & \multicolumn{3}{|l|}{ Model C } & \multicolumn{3}{|c|}{ Model D } \\
\hline & $\beta$ & SE & $\mathrm{e}^{\beta}$ & $\beta$ & SE & $\mathrm{e}^{\beta}$ & $\beta$ & SE & & $\beta$ & SE & $\mathrm{e}^{\beta}$ \\
\hline $\mathrm{D} 1^{\mathrm{a}}$ & $-1.929 * * *$ & .260 & .145 & $-2.027 * * *$ & .306 & .132 & $-1.894 * * *$ & .374 & .150 & -.782 & .748 & .457 \\
\hline $\mathrm{D} 2^{\mathrm{a}}$ & $-1.110 * * *$ & .214 & .330 & $-1.202 * * *$ & .265 & .301 & $-1.038 * * *$ & .346 & .354 & .083 & .739 & 1.086 \\
\hline $\mathrm{D}^{\mathrm{a}}$ & $-.676 * *$ & .224 & .508 & $-.737^{* *}$ & .270 & .478 & -.535 & .348 & .586 & .636 & .755 & 1.889 \\
\hline $\mathrm{D} 4^{\mathrm{a}}$ & $-1.494^{* * *}$ & .334 & .224 & $-1.558 * * *$ & .365 & .211 & $-1.346 * * *$ & .432 & .260 & -.099 & .810 & .905 \\
\hline Minority $^{b}$ & & & & -.166 & .264 & .847 & -.117 & .282 & .890 & -.307 & .300 & .736 \\
\hline Gender $^{c}$ & & & & .281 & .249 & 1.325 & .239 & .256 & 1.271 & .207 & .260 & 1.230 \\
\hline $\begin{array}{l}\text { Math } \\
\text { SAT }^{d}\end{array}$ & & & & & & & $-.687^{* *}$ & .288 & .503 & -.479 & .305 & .619 \\
\hline Verbal SAT & & & & & & & $.607^{*}$ & .293 & 1.836 & $.680^{*}$ & .303 & 1.975 \\
\hline $\begin{array}{l}\text { Freshman STEM } \\
\text { GPA }\end{array}$ & & & & & & & & & & $-.467 *$ & .200 & .627 \\
\hline $\begin{array}{l}\text { Freshman Non- } \\
\text { STEM GPA }\end{array}$ & & & & & & & & & .016 & .264 & 1.016 & \\
\hline$-2 \mathrm{LL}$ & $403.903^{\star *}$ & & & 402.198 & & & $394.720^{*}$ & & & 387.90 & & \\
\hline Change in -2LL & & & & 1.705 & & & 7.478 & & & 6.816 & & \\
\hline
\end{tabular}

a. Dummy variables representing the main effect of time period

b. 1 = Minority, $0=$ White

c. $1=$ Female, $0=$ Male

d. $1=\geq 700,0=<700$

${ }^{*} \mathrm{p}<.05 \quad{ }^{* *} \mathrm{p}<.01 \quad{ }^{* * *} \mathrm{p}<.001$

The hazard probability estimate for white students is higher than for minority students at the beginning of sophomore year, before evening out at the beginning of the junior year. Additionally, when examining the hazard and survival probability estimates for gender differences, we witness a greater hazard probability for women up until the beginning of the senior year, where we see the hazard probability at this time period to be higher for men. This signifies that, while the hazard is greater for women earlier in their studies, the women that persist in STEM majors up until the senior year have a greater survival probability than the men remaining at this point of their undergraduate careers. While King (2016) found that women are as likely as men to persist in university STEM majors, both in STEM majors with a significant minority of females as well as the life sciences, there appear to be differences in the timing of STEM attrition which should be examined further. 
Perhaps the most significant finding in the study was the revelation regarding college entrance examination results and STEM major persistence, particularly the effect of the highest-scoring students on the verbal section of the SAT. Perhaps unsurprisingly, the study found a significant difference between the highestscoring students on the math SAT section and lower scoring students, with the odds of changing from a STEM major to a non-STEM major for the highest-scoring students about .5 times that of lower-scoring students. However, the students with the highest verbal SAT scores were significantly more likely to depart from STEM majors for non-STEM majors, with odds almost two times that of students with verbal SAT score of under 700 . Chen \& Soldner (2013) also found a significant difference in STEM attrition based on achievement, finding that the probability of students leaving STEM majors was higher in the cohort of high-achieving students than the cohort of low-achieving students. The findings in the current study suggest that the disciplines in which students have high achievement have a role in predicting the odds of STEM attrition. Students with very high achievement on the verbal SAT may choose to switch to majors which demand greater verbal skills after experiencing general education classes during their first few semesters. Beggs, Bentham and Taylor (2008) find that the greatest factor influencing students' major choice is a match with their interests, while financial success is ranked lowest. High achieving students may find that a non-STEM major is of greater interest, and without a factor such as financial success to influence them to remain in a STEM major, they may leave STEM for another discipline. Further research should be conducted to examine this finding, particularly in highachieving student populations.

This study, of course, has its limitations. While the data set was of particular interest due to the student population in question, the data is quite dated. Future research should examine similar questions to examine whether STEM persistence is still affected differently between math achievement and verbal achievement, as measured on the SAT. Additionally, the size of the dataset prevents the results from being generalizable to the student population as a whole. A greater number of students would allow researchers to draw stronger conclusions about whether and when high-achieving students do not persist in STEM majors. However, the discrete-time survival analysis used in the study gives keen insight to higher education administrators and policymakers to better understand when certain intervention programs for certain student populations may be needed most, and when they may be most effective.

\section{References}

Astin, A. W. (1999). Student involvement: A developmental theory for higher education. Journal of College Student Development, 40(5), 518-529.

Beggs, J. M., Bantham, J. H., \& Taylor, S. (2008). Distinguishing the factors influencing college students' choice of major. College Student Journal, 42(2), 381-394.

Carrell, S. E., Page, M. E., West, J. E., \& National Bureau of Economic Research. (2009). Sex and science: How professor gender perpetuates the gender gap. Cambridge, Mass: National Bureau of Economic Research

Chen, X. \& Soldner, M. (2013). STEM attrition: College students' paths into and out of STEM fields. National Center for Education Statistics, Institute of Education Sciences (NCES 2014-001). Washington, DC: U.S. Department of Education.

Estrada, M., Burnett, M., Campbell, A. G., Campbell, P. B., Denetclaw, W. F., Gutierrez, C. G., . . Z Zavala, M. (2016). Improving underrepresented minority student persistence in STEM. CBE - Life Sciences Education,15(3), 1-10.

Glass, J. L., Sassler, S., Levitte, Y., \& Michelmore, K. M. (2013). What's so special about STEM? A comparison of women's retention in STEM and professional occupations. Social Forces, 92(2), 723-756.

Griffith, A. L. (2010). Persistence of women and minorities in STEM field majors: Is it the school that matters? Economics of Education Review, 29(6), 911-922. 
Ishitani, T. T. (2008). How to explore timing of intervention for students at risk of departure. New Directions for Institutional Research, 2008(137), 105-122.

King, B. (2016). Does postsecondary persistence in STEM vary by gender? AERA Open, 2(4), 1-10.

Kokkelenberg, E. C., \& Sinha, E. (2010). Who succeeds in STEM studies? An analysis of Binghamton University undergraduate students. Economics of Education Review, 29(6), 935-946.

Lacosse, J., Sekaquaptewa, D., \& Bennett, J. (2016). STEM stereotypic attribution bias among women in an unwelcoming science setting. Psychology of Women Quarterly, 40(3), 378-397.

Min, Y., Zhang, G., Long, R. A., Anderson, T. J., \& Ohland, M. W. (2011). Nonparametric survival analysis of the loss rate of undergraduate engineering students. Journal of Engineering Education, 100(2), 349-373.

Morrison, L., \& Silverman, L. (2012). Retention theories, models and concepts. In A. Seidman (Ed.), College student retention: Formula for student success (pp.61-80). Lanham, MD: Rowman \& Littlefield.

Murtaugh, P., Burns, L., \& Schuster, J. (1999). Predicting the retention of university students. Research in Higher Education, 40(3), 355-371.

Price, J. (2010). The effect of instructor race and gender on student persistence in STEM fields. Economics of Education Review, 29(6), 901-910.

Rask, K. (2010). Attrition in STEM fields at a liberal arts college: The importance of grades and pre-collegiate preferences. Economics of Education Review, 29(6), 892-900.

Seidman, A. (2012). College student retention: formula for student success. Lanham, MD: Rowman \& Littlefield.

Seymour, E., \& Hewitt, N. M. (1997). Talking about leaving: Why undergraduates leave the sciences. Boulder, Colo.: Westview Press.

Simon, R., Aulls, M., Dedic, H., Hubbard, K., \& Hall, N. (2015). Exploring student persistence in STEM programs: A motivational model. Canadian Journal of Education, 38(1), 1-27.

Singer, J. D., \& Willett, J. B. (2003). Applied longitudinal data analysis: modeling change and event occurrence. New York: Oxford University Press.

Tinto, V. (1975). Dropout from Higher Education: A Theoretical Synthesis of Recent Research. Review of Educational Research, 45(1), 89-125.

Tinto, V. (1993). Leaving college: rethinking the causes and cures of student attrition. Chicago: University of Chicago Press.

Ulriksen, L., Madsen, L. M., \& Holmegaard, H. T. (2010). What do we know about explanations for drop out/opt out among young people from STM higher education programmes? Studies in Science Education, 46(2), 209-244.

Ware, N. C., \& Lee, V. E. (1988). Sex Differences in Choice of College Science Majors. American Educational Research Journal, 25(4), 593. 